\title{
Selling Streetness as Experience. The Role of Street Art Tours in Branding the Creative City
}

Key words: London street art, Shoreditch, streetness, street art tour, creative city, place branding

This paper examines the street art tours industry, investigating its function in constructing the geographic, economic and symbolic value of street art. London's street art world has achieved substantial institutional endorsement as a proper urban creative practice, including by local councils and private developers, art galleries and book publishers. This paper examines the role of walking tours in holding up street art as an urban cultural product, by arguing that tours construct and legitimate London's street art scene through the strategic deployment of an authoritative discourse. Street art tours' routes and locations are then integrated into a longer lineage of endorsements for the cultural field of street art, and interpreted as branding strategies for the creative city. The paper concludes with remarks about the role of walking tours in gentrification and urban change, with a focus on how street art and murals contribute to performing Shoreditch as a hub of vibrancy and urban creativity.

\section{Street art tours: diminished walking and authoritative discourse}

Much of the literature on walking tours comes from tourism studies, and it emphasizes the cooperative and social value of these activities (see, for example, Zillinger at al, 2012, Mykletun, 2013, Hallin and Dobers: 2012). Tours are processes of discovery, first and foremost through mobility, but they involve a themed and dysbalanced exchange between a guide and a group of participants. Moving in a choreographed manner and as part of a group, offers a fabricated experience of places, which are strategically packaged and presented in a certain way, at a certain rhythm. Street art walking tours in particular, offer a rigid, well-rehearsed, noncollaborative presentation of their material, whose selection and presentation leaves little room for contingencies. Criminologist Alison Young describes street art tours as having a 'deadening' effect (2016: 111) and presents their mechanics as a 'diminished kind of walking' (2016: 119):

The walking tour is accessible only to those who pay the fee, and it follows pre-designed itineraries. Detours and meanderings off-route are not possible. Conversation is 
controlled by the guide. Encounters with the street artworks take place for just the amount of time that can be contained within the time limit of the tour.

Art historian Peter Bengtsen also describes his experience of a street art walking tour as having 'a certain unnatural, almost Disneyesque, feel to it' and attributes his lack of immersion to the ready-planned character of the tour (Bengtsen 2014: 158). It is not just that street art tours deprive one of the sense of individual discovery valued so highly by street art lovers, but they also play a substantial role in drawing the boundaries of the street art world, by naming and validating its art works, and enabling the formation of its audiences. Show it on the tour, and it is art; don't show it, then it is probably not - and all participants with their camera phones and social media accounts will unwittingly attest to that.

Tours impose masses of people on perhaps otherwise quiet streets, severely altering the street dynamic through their presence. This occurs through temporary changes in traffic and pedestrian flows or street centres of gravity, as well as through long-lasting effects like touristification and gentrification, which I will return to in the last part of the paper. City streets, with their displays, affordances and hostilities, are the very material of these changing dynamics. They enable new discoveries but also create spurious zones of heightened attention, setting the terrain for even more tours, and eventually becoming significant agents of urban change. London has seen this happen in areas such as Shoreditch and Brick Lane, where the density of street art tours has contributed significantly to the affirmation, muralisation and touristification of many streets and surfaces. 


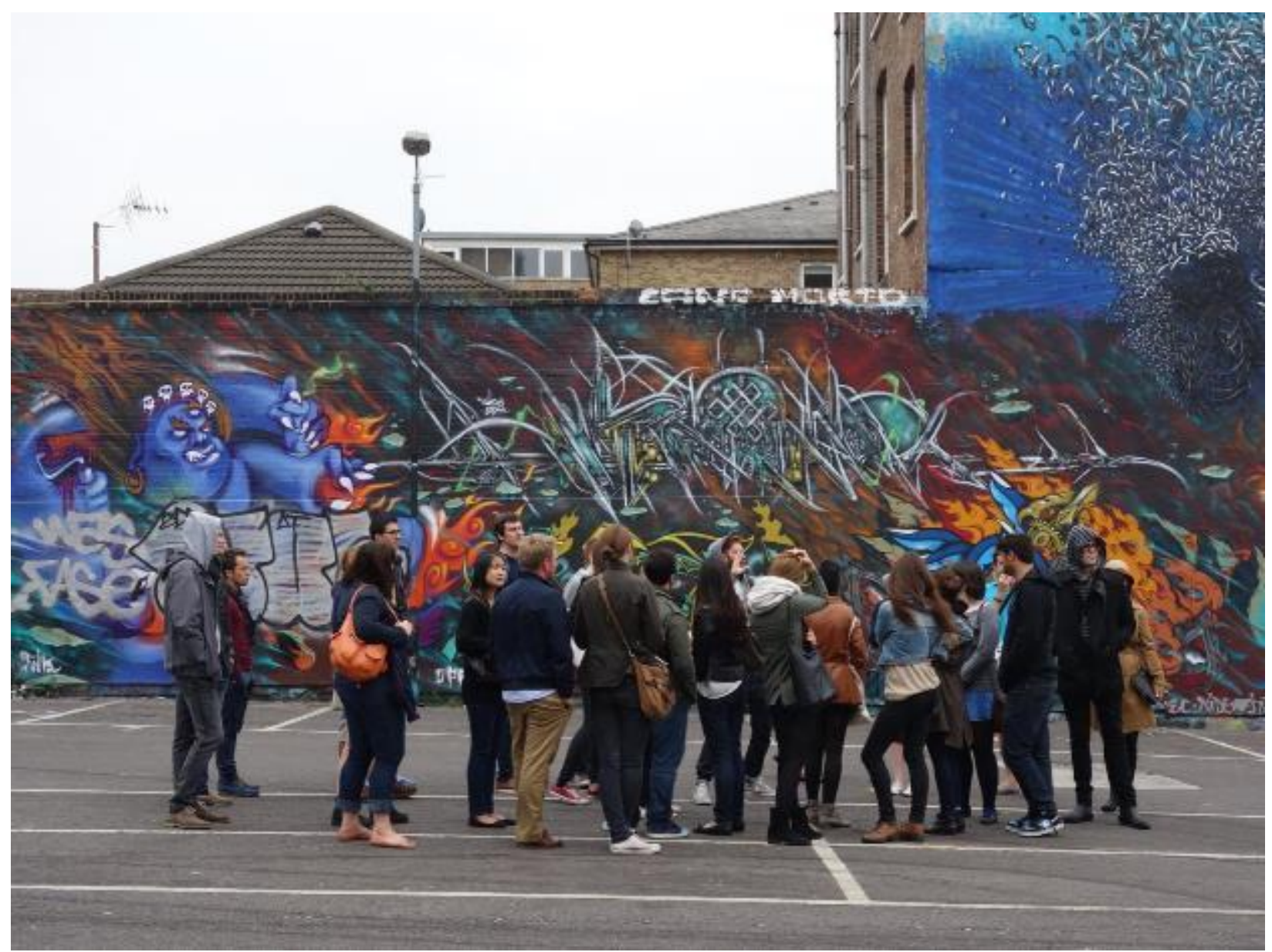

Figure1. Average size street art walking tour in a car park on Sclater Street, with around 20 participants. Since this research was conducted, this plot of land has been redeveloped and transformed into high-rise apartments.

The touring companies whose work I have observed for this paper are Shoreditch Street Art (SSA), Alternative London (AL) and Street Art London (SAL), alongside Insider London and London Graffiti. The paper is not in any way a critique of the quality of their service, nor is it an appraisal of their work. My approach was to map and observe their work in two separate sessions conducted one year apart, recording their movement and discourse, and correlating it with the providers' marketing strategies. I noted their comparable approaches and stances by mapping their routes and photographing their demonstrations, and used the resulting visual material as an interpretive tool. For recording the routes, I worked with a GPS movement tracking app and superimposed the resulting trails, to create a visual demonstration of the limited and strategic territories of tours. Photographic images are annotated throughout, in an attempt to decipher the codes of touring practices and their objects of production. Working with annotated photography 
is a method I have been developing in my research, to propose images as arguments and untangle the evidence they articulate and convey (see Andron 2017).

Based on these research strategies, a prevailing touring process and mode of discourse has emerged. It became apparent that most guides take very little time to reflect on their own practice during the tours, and refuse to acknowledge their roles in configuring London's street art world. Guides commonly present themselves as mere observers and commentators, whose work bears no impact on the locations and types of street art works they include on their tours. Reality, however, shows a different story, as tours daily specify not only the content of this street art world, but also its locations and narratives. They are influential in determining which surface inscriptions London welcomes, and where they are to be placed. It is not just that tours go where the street art is; but the street art will come where the tours are, to make use of the increased footfall and visibility produced through this organized walking.

These changes are possible because tour guides operate from a position of authority, which they assume by branding their businesses and creating complex infrastructures to support them: websites, blogs and social media pages, calendars and booking systems, schedules, meeting points and predictive routes, vetted employees and, crucially, strong presences on rating websites. The power of tour guides therefore comes not only from their knowledge of the scene, but also from their capacity to present this knowledge under strategically organized circumstances.

Language is a key element of walking tours, and guides will use it as an instrument of description, information, entertainment and education (Hallin and Dobers 2012), while also performing language as an instrument of power (Bourdieu 1991). When they name artists, describe inscriptions, or lead the way to the next objective, tour guides make use of their roles to create symbolic capital for street art. Information comes from experts and is therefore accepted as truthful and authoritative, demonstrating the power of emplaced narrative in creating a situation of belonging for street art. The authority of tour guides is also enabled by the precarious nature of street art works, the elusive identity of some artists, and the artists' lack of control over their work's integrity. Discursive agency can therefore be claimed more easily by the guides, whose warrant confers them several executive privileges. For example, pointing to a work in situ 
can even be more important than saying something about it. This became evident in many instances when guides were offering partial, distorted or even fake information about the works they were showing (see also Young 2016: 102-6 for inaccuracy of guides' information). Misattributing work, perpetuating unverified information and proposing unevidenced claims were just a few of the actions that could safely be conducted from a position of authority, albeit sometimes unintentionally.

Bourdieu suggests that the symbolic efficacy of discourse lies in the relationship between the properties of discourses, the properties of the person who pronounces them, and the properties of the institution which authorizes the pronunciation (1991). The success or failure of a touring proposal is therefore to be found at the intersection of the content of the tour (what is being said and how), the ability of the guide (their background, eloquence and power of entertainment), and the success of the touring organization (online presence, number of reviews, quality of reviews). Participants' assessment of the tours takes place in situ, but the dissemination of that information happens online, through digital communication platforms where the tours promote themselves, showcase their content and take future bookings.

Tour guides' jurisdictions are justified by their branding strategies and customer reviews. Participants on tours empower guides in their positions, turning them into what Bourdieu called 'authorized representatives' for the world of street art:

The authorised spokesperson is only able to use words to act on other agents [...] because his [sic] speech concentrates within it the accumulated symbolic capital of the group which has delegated him and of which he is the authorised representative. (Bourdieu 1991: 111, original emphasis)

Guides' websites, social media pages and customer ratings all work towards legitimising their authority, while building on the symbolic capital of the institution they represent. Each new booking is a recognition of the guides' credibility, and an endorsement of their product. Bourdieu proposes three markers of recognition, stating that the discourse must be authored:

- in a legitimate situation. Guides will often hold signs with their companies' logo when waiting for participants to arrive. They will begin by repeating the name of the touring 
company, asking everyone to 'gather round' and reassuring them that they are in the right place. Financial conventions are also discussed in the beginning, as participants are being told when they must pay and how much they are expected to contribute.

- in front of legitimate receivers. Participants will receive emails and/ or text messages prior to the tour, asking them to confirm attendance, and the guides bring their own lists of people for the day, making sure they are working with all confirmed participants and there were no unexpected additions to the group.

- according to legitimate forms. Guides are always conscious of the group's movement and urge participants to mind the traffic; they make jokes to keep participants entertained; and they stick to established routes, start and end points, and timings for the tour.

These practices set the stage for the deployment of arguments and provide the rationale by which tour guides can perform their duties as vetted experts of the street art world.

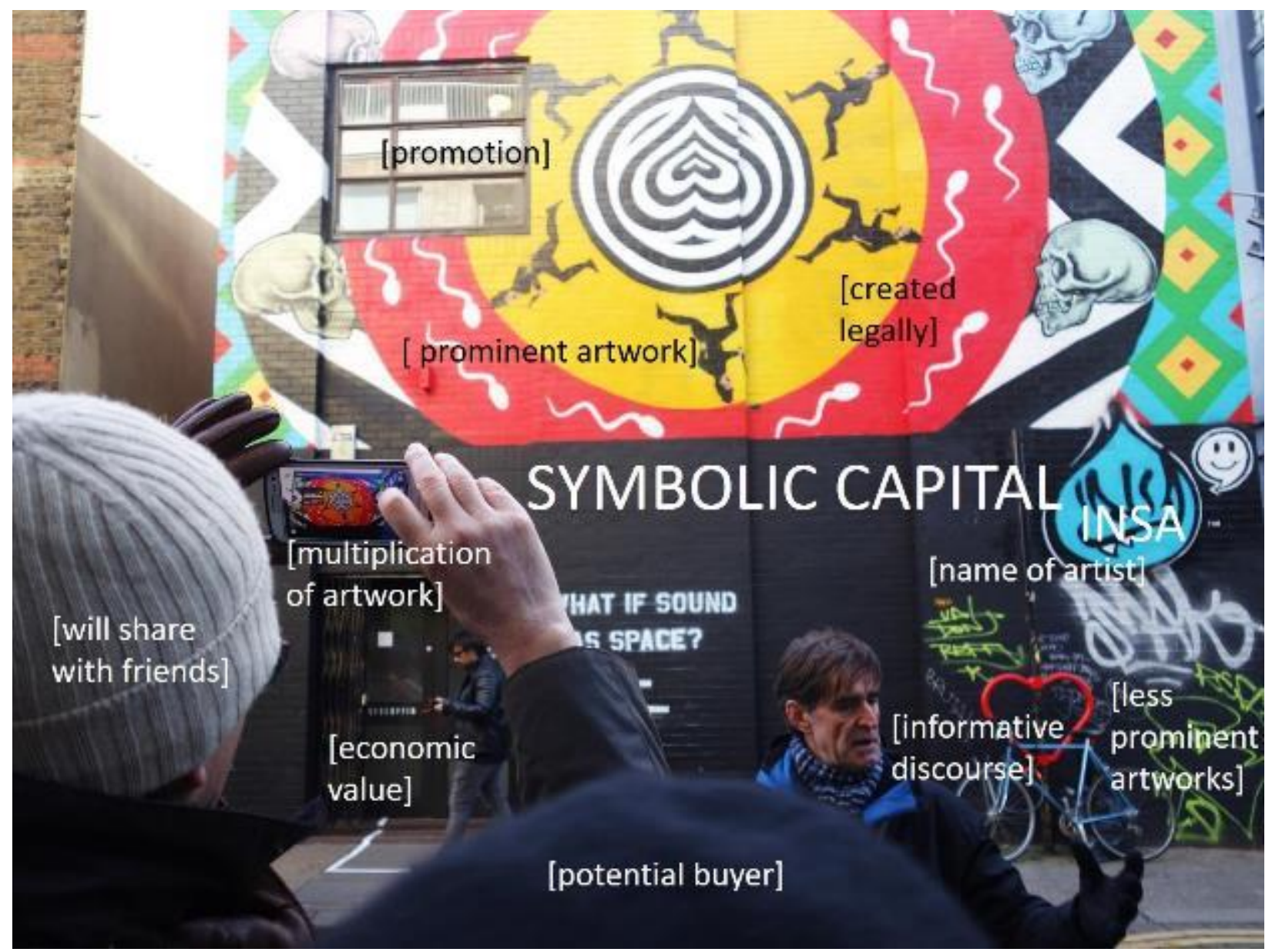

Figure2. The formation of the symbolic capital of street art. 


\section{Streetartness and the belonging of street art}

While tours contribute significantly to the formation of London's street art world, street art was initially made acceptable by authorities and the private sector of the art market, which was busy configuring independent, often anonymous surface markings into a marketable artistic commodity. From a low-key, independent, creative surface production, this endorsement allowed street art to evolve into a fully developed art movement, which could then be harnessed in assistance of governance agendas supporting the creative city: it became creative 'in the dogmatic sense of the word' (Mould 2015: 132). Sanctioned street art and murals have not only been deemed acceptable, but they have become potentially lucrative for local authorities, to support place branding and the development of the creative city (on the mutual valorisation of place and street art, see Dickens 2010, Banet-Weiser 2012, McAuliffe 2013, Mould 2015, Evans 2016, Brighenti 2016).

Streetartness is therefore less a property of the inscriptions on city surfaces, and more a construct of the discourses which go up around them. This is supported by Becker's (2008) and Bourdieu's (1992) sociologies of art, which suggest that art worlds and objects are shaped by several forces and actors (including, in our case, walking tours), who define and decide what art is, where it can be found, how it should be valued and cared for. For street art to belong then, it needs a network of agents with a good understanding of its spaces and with some command over them: property developers who welcome street art on their hoardings; local councils who authorise paint jams and street art festivals; editors who publish picture books of street art from around the world; Instagram photographers with thousands of followers; and tour guides who can produce a targeted audience of hundreds of people in situ, every day.

All these agents play an active role in in constructing the cultural field of street art and establishing its symbolic capital (Bourdieu 1992). Symbolic capital is an initial form of legitimation that characterizes art works within their fields, and can be defined as the discursive material that surrounds a work of art and substantiates its status. This is measured in recognition, consecration and prestige, and takes the form of articles, images, events, discussions, or any other actively manifested interest in a form of artistic production. In the case of street art, 
walking tours are one of the institutions productive of symbolic capital, which is then bestowed selectively upon certain works and artists from an authoritarian position.

This process of street art normalization took place through what legal scholar Sarah Keenan (2015) calls a relationship of belonging, which can be understood as the opposite of geographer Tim Cresswell's analysis of graffiti as being out of place (1996). Keenan's belonging and Cresswell's out-of-placeness are both geographical analyses of occupation and propriety, which demonstrate how power reveals itself by controlling what belongs and what doesn't belong, what can and what should not be visible.

Unlike some street art, graffiti was legally configured as a crime against private property and one against public order, based on what Cresswell (1996) defined as a logic of out-of-placeness, or graffiti appearing where it shouldn't be. Cresswell (1996: 39) speaks of a hierarchy of visual rights to places, whereby 'those who can define what is out of place are those with the most power in society'. Graffiti was therefore defined as non-desirable through a complex legal and ideological battle, but what concerns us here is the ways in which street art was configured as belonging to certain urban environments and being in its proper place, and how street art tours have contributed to this geographic legitimation.

Keenan, in contrast, defines property as 'a spatial formation that occurs when relations of belonging are held up by the spaces in and through which those relations exist' (2015: 65). She understands belonging as spatially contingent and directly related to property and propriety: it is a relation which must be held up and enabled institutionally and culturally. Moreover, belonging is not just a subject-object relationship (an object belongs to a subject), but also a part-whole relationship, where attributes, qualities or characteristics belong to a subject or thing. For example, certain inscriptions are not only held up as belonging to their surface environments, but they also belong to the discursive classes which have been developed around them: some inscriptions are shown to be art (street art), and this class reflects on all their other components. Every time an inscription is singled out as street art, there is an implication of spatial legitimacy and belonging, a tacit endorsement which comes from its association with street art as a whole. In Keenan's words, part-whole belonging comes with the privileges of the social relations and networks that constitute the whole, and tours are the direct enablers of these relations. With each 
completed walk, guides will have extracted a finite number of inscriptions from the surface chorus, and imprinted upon them streetartness, belonging and propriety.

\section{What is shown: the selection and naming of street art}

The number of inscriptions that can be found on the route of any street art tour could not possibly be accommodated in the scope of a 2-3-hour walk, and doing this would defeat the organizing principle of the tours. Some inscriptions have anonymous authors, others are deemed to show little artistic merit, while others seem to display few qualities that would make them stand out from their surface environments - and they are the first ones to be overlooked on the tours, and therefore deemed not street art. Guides will almost always select work whose authorship they can attribute, leaving anonymous marks outside the scope of their discourse, and cutting out an important part of the wall writing culture to focus on the street art. By singling out certain works and naming their makers, the tours contribute to the creation of a culture of artistic fame. They parade a spectacle of carefully curated images in front of participants, while exercising their authority to decide on artistic worth. The decision to include certain images implies the exclusion of everything else, the message being 'this is what you should see', and then 'I can guide your gaze in the best way'. 


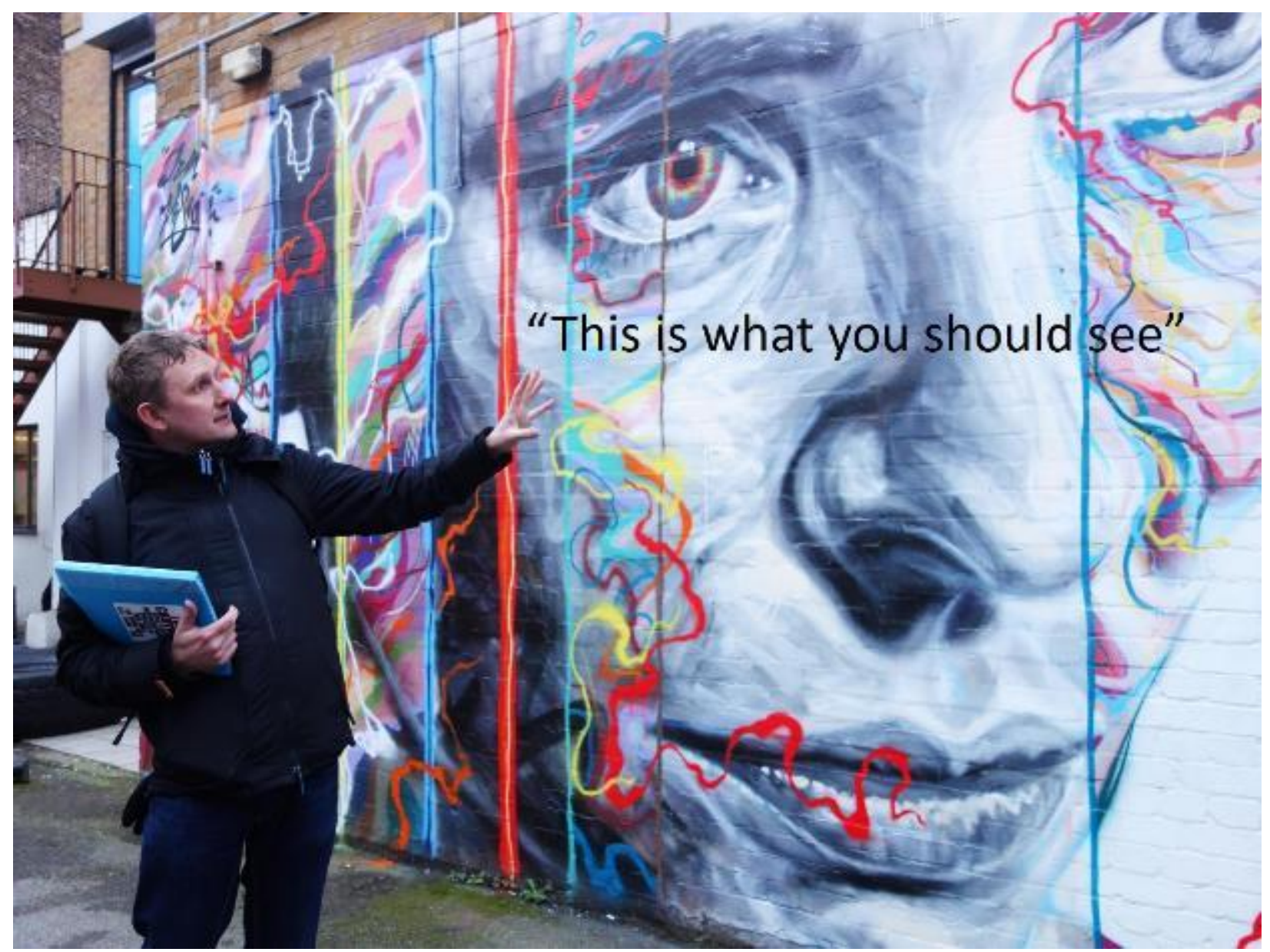

Figure3. The gesture of pointing to a particular artwork operates a spatial and aesthetic selection, suggesting to participants what they should pay attention to.

All guides acknowledge that they perform a selection, but they rarely reflect on the mechanics of their decision and the reasons behind it. 'The tour could last 24 hours, but it is limited to 2 hours' (AL); 'The tour covers about a third of all Shoreditch street art'; 'I have only stopped and shown you $10 \%$ of what we saw on the tour' (SSA). Indeed, the ever-changing nature of surface inscriptions seems to force guides to adapt their routes and image selection. However, after repeated participation on these tours, it became apparent that there is a relatively limited number of street art works that guides show on their routes, reaffirming the importance of selection over variation, and of named artist over anonymous scribbler.

The selection of material during a street art tour implies not only the symbolic extraction of visual material from the surfaces of the circuit, but also, crucially, the naming of this material, the attribution of the work to a named author. From signed prints to followers on social media, 
mentions in publications and appraisals on tours, the named street artist is a fundamental element in the legitimation and empowerment of the cultural field of street art. Banksy, Ben Eine, Shepard Fairey, ROA, Ben Wilson, Invader, Jonesy, C215, Paul Don Smith or Conor Harrington are part of the roster of artists named on all London walking tours, reinforcing these artists' standing within the field with each new mention.

Naming generates uniqueness and recognition, and enables extraction of specific works and their makers from their surface environments. This process of extraction was discussed by sociologist Mubi Brighenti as a measurement of value, whereby objects deemed artistically worthy are nominated and strategically separated from their environments. Equally, tour guides' discourse is not simply a recording of pre-existing value, but a creation of the reality of that value, which will then be adopted by local governance as an urban asset (Brighenti 2017). Guides must first be able to identify who made works from the tours circuit, which is a principal measure of their expertise. Without names, there would be no artists, there would be only expression, and street art requires artists to exist. The name makes the sign, it rises and qualifies it, but it also significantly alters it. And the cultural field of street art becomes one of namable artists, not one of inclusivity, collective visibility or agonistic surface commons. 

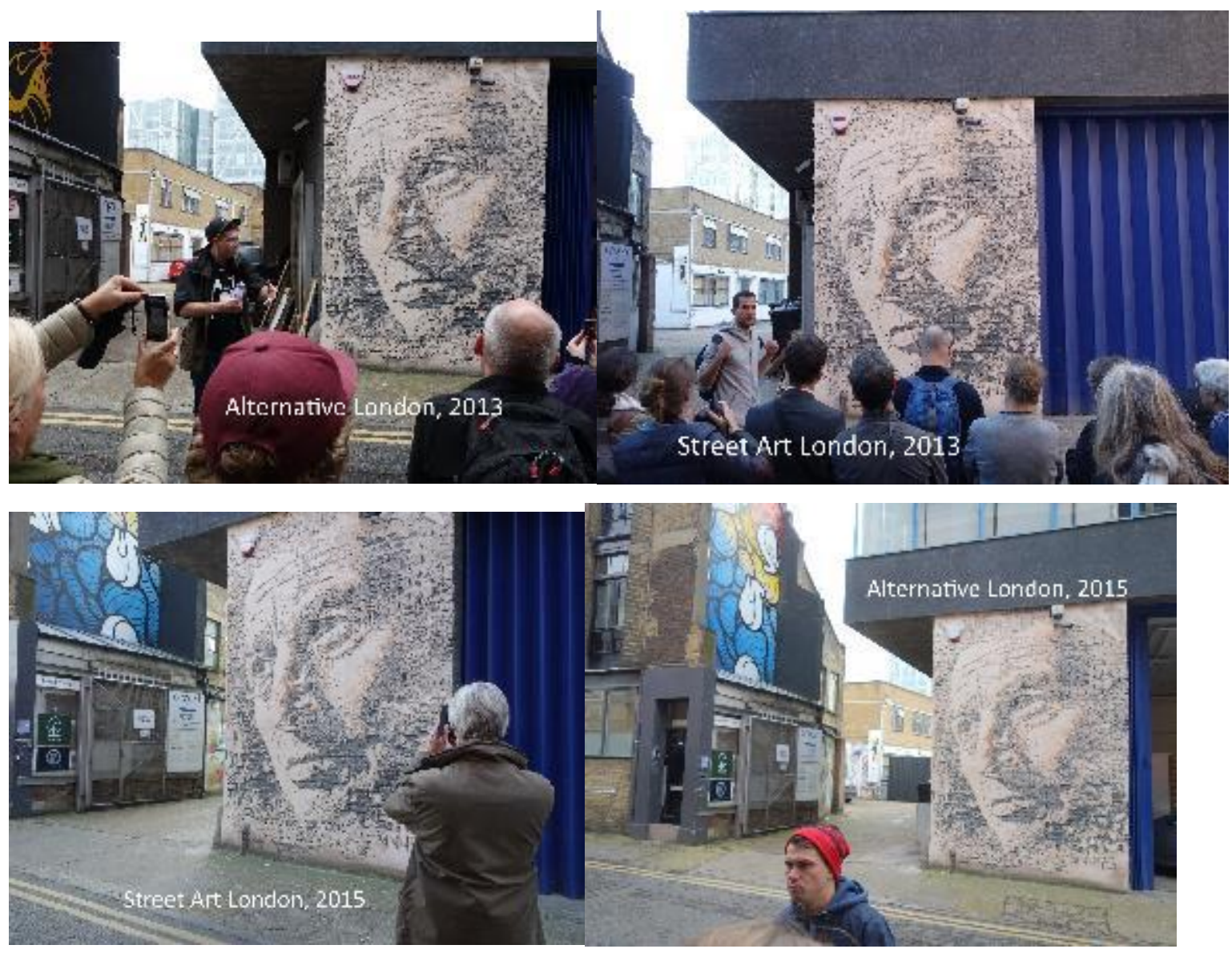

Figure4a-d. A work by Portuguese artist Vhils which was made part of several tour narratives. The building it stands on has since been demolished. 

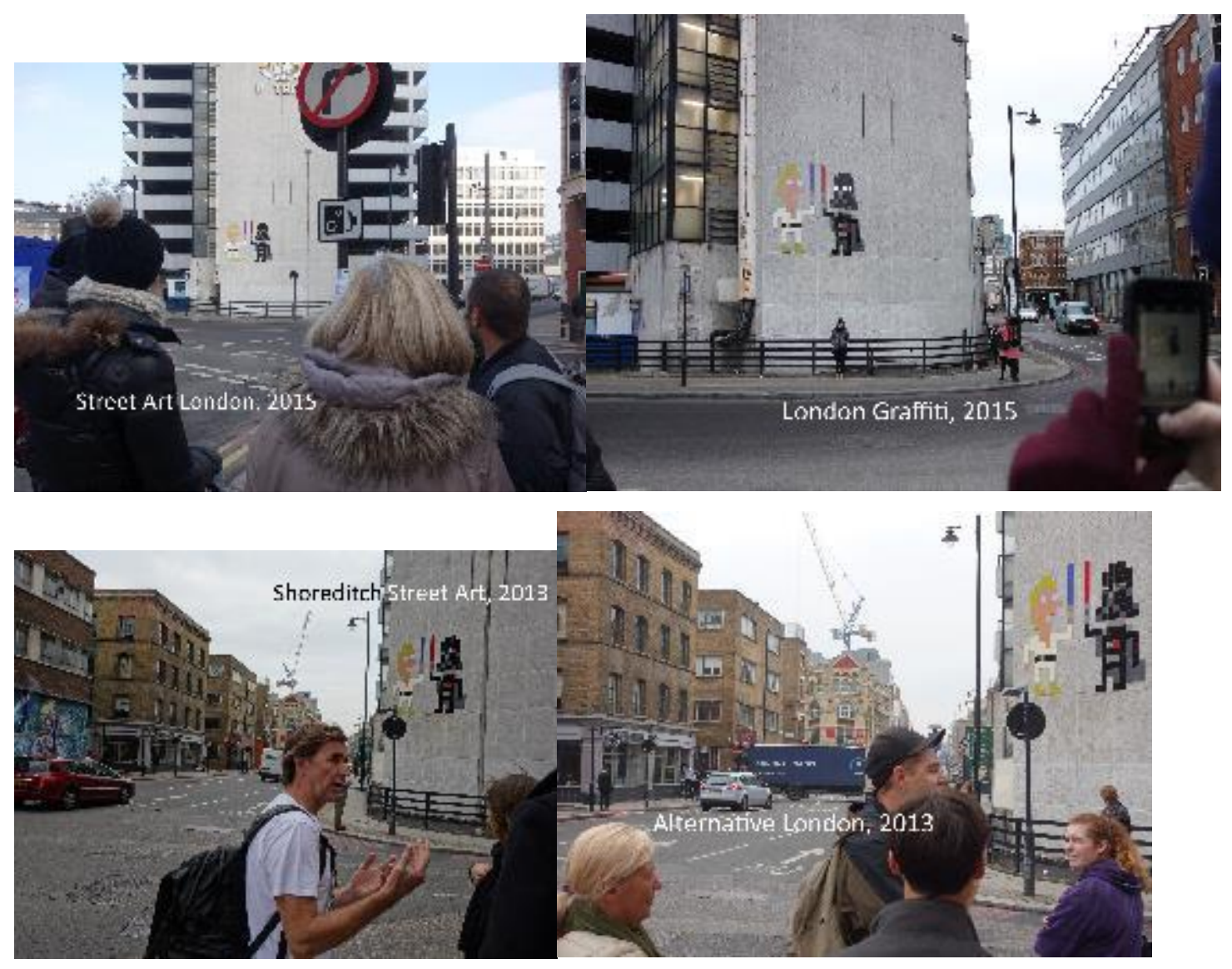

Figure5a-d. Mosaic artist Invader finds his way onto four different walking tours.

Names enable the creation of taxonomies, or what Keenan referred to as the part-whole relationship. Names illustrate the power of language to shape reality, not just to describe it, and to categorise, classify and order the visual material on surfaces based on clear agendas of belonging and out-of-placeness. Naming enables specific politics and justifies acting upon them, we don't want graffiti in our neighbourhood, and street art is one of the most welcome features of a new development. We, then, as photographers, bloggers, instagrammers who participate in the tours, become an integral part of the cultural field of street art and enable this version of it to be held up. We are its audience and promoters, we are the discourse that selects and shapes the practice, the second-degree curators whose impression of the meaning of street art will travel through our tales and images, physically and digitally. 
Turning symbolic value into economic value is a challenge for all artists who are building a creative career, but street artists are offered an advantage through extra support from the tours: their works are highlighted to thousands of people every week, their names are repeated emphatically, their projects are presented and referenced, and they are placed on a free digital distribution network by having their work photographed and posted online. All these actions are part of the dynamics of walking tours, and they form a collective discourse of endorsement for a carefully selected number of artists and locations. Significantly, the artists whose work makes the objective of all street art tours, have all had their work shown either in group or solo shows in galleries around London and the world, reinforcing the tours' importance in supporting a culture of artistic commodities. Guides characterize works as skillful, durable, respected, captivating, iconic, and use their authority to encourage consensus with respect to the artistic value of certain works. Sometimes, consensus will be achieved even without arguments, through the simple action of pointing and naming, which is a basic mechanic of any tour. This agreement is then perpetuated and naturalized on site and online, enabling street art not only to be held up as belonging to the city, but also as bestowing value upon it (Brighenti 2016).

London's attraction as a centre of street art comes not only from its physical displays, but also from the extreme vigor with which these are captured and circulated through digital channels. This recalls Bengtsen's narrative of his group walk in Williamsburg (New York), 'where artworks were anticipated and to some extent came across as familiar photo opportunities' (Bengtsen 2014: 159). It is also the reason why several guides point to empty walls where there used to be Banksy artworks as far as ten years back, and participants show a similar level of enthusiasm as if having seen the works themselves. Painting a mural in London promises visibility not only for the wall itself, but for hundreds and thousands of its digital avatars, whose rate of re-production skyrockets with every tour, retweet and Instagram post. Working in London is therefore seen as an opportunity to advertise one's practice, as artists' online accounts are mentioned repeatedly, alongside hashtags, social media circulation, or the number of times a piece is posted online. Inscriptions on walls then become mere triggers for a major cultural field that develops digitally, and can support itself with very little input from the physical city. Street art tours act as facilitators between these two dimensions, activating streets and surfaces through an encounter with picture-hungry, snapchat-savvy participants. 


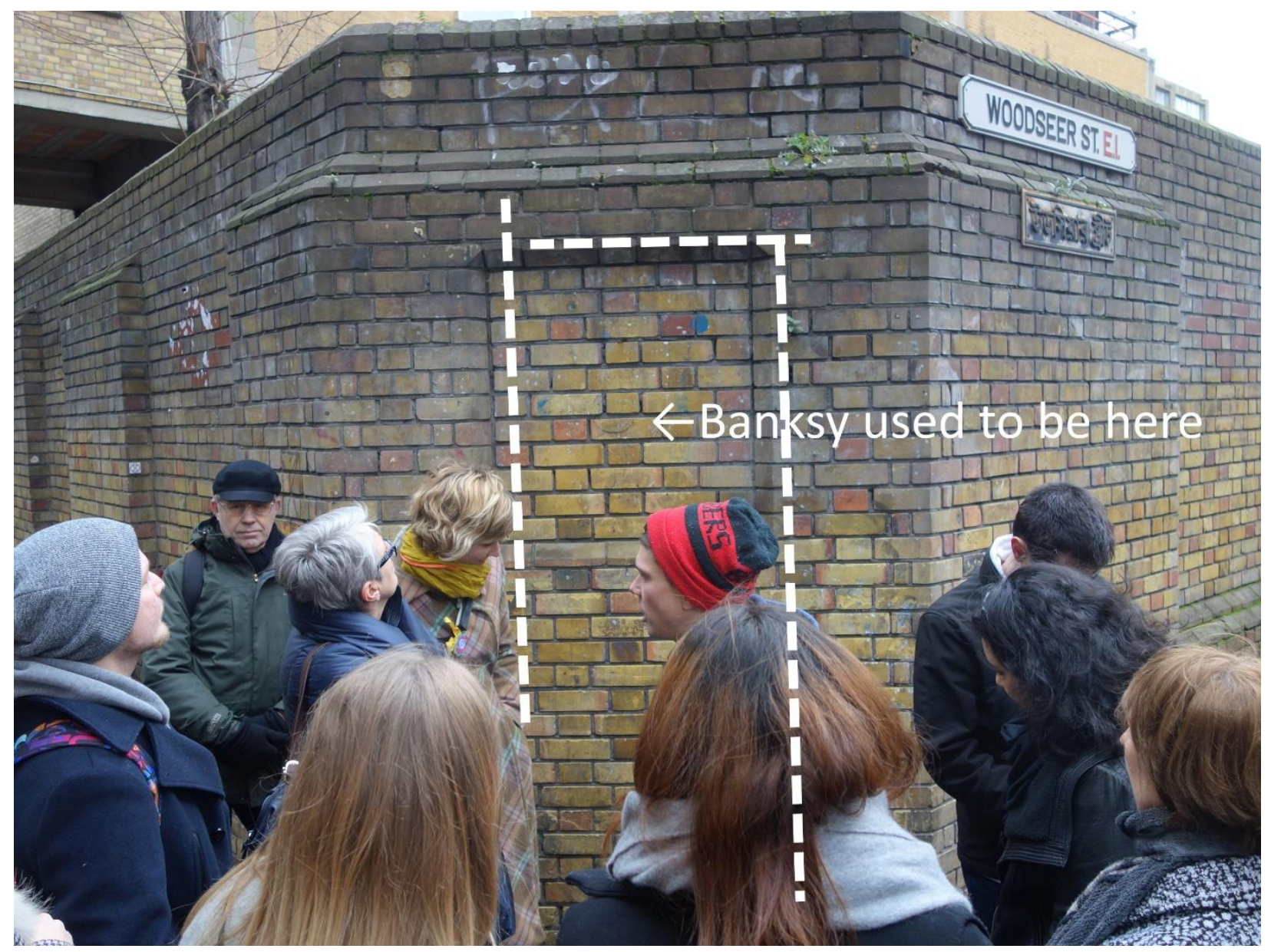

Figure6. Plain walls conjure the absent works of superstar artists.

\section{Where it is shown: streetness and the pre-dictive geographies of Shoreditch}

Street art tours contribute to the creation of Shoreditch as an urban brand by encouraging the consumption of place as product, and selling it as a scene of urban authenticity and edgy streetness, where a tour booking will buy you the experience of place and art. The street therefore becomes a site of mediated, commodified cultural consumption, instead of 'a place of active, physical praxis where one could publicly reflect and act upon the world so as to transform it' (Schacter 2014: 226). Streetness is now a significant value-adding element to the branding of municipal art trails and the narratives of street art walking tours, as the reclamation of the streets is being depoliticized and transformed into an urban branding strategy. 
For street art tours, the street is a geographic and cultural resource which can generate capital in the form of streetness, provided this is carefully presented as self-made and authentic. All institutional support and endorsement must therefore be downplayed, as argued by communications scholar Sarah Banet-Weiser, specifically in relation to street art:

Part of the marketing of an urban space now involves navigating the inherent tensions between corporate sponsorship of the arts and culture and maintaining a sense of 'authenticity' to those same arts - especially to those creative practices such as street art and graffiti. (Banet-Weiser 2012: 111)

The street becomes part of a wider culture of consumption as a mode of expression, exemplified by the place-consuming mechanics of street art tours. Their destinations are not simply containers of relevant artworks, but become cultural destinations in themselves. Banet-Weiser (2011; 2012) suggests that this type of place branding is normative for neoliberal cultural economies, which are heavily reliant on certain types of cultural products such as street art. Moreover, branding also engenders a more corporatized and homogenous urban aesthetic. It has 'direct political agency and subtly removes the images of a city's social problems from the public imaginary' (Mould 2015: 31). As part of the place branding process, tours collapse authenticity with its marketability, and use street art to sell a false notion of place (Schacter 2015). Shoreditch as an entire area is promoted as having streetness, a characteristic that has little to do with the historical development of the area, and is part of the language of branding authenticity (see Proud 2014 for a mainstream media critique of 'Shoreditchification').

Most tourists choose to be guided to the areas with the highest street art density because they are guaranteed to find what they are looking for, and the choreographed experience is not contingent on any trajectory hazards. In fact, it is the promise of access to otherwise problematic spaces that attracts a lot of participants to these tours, as they want to see a part of London which they feel they wouldn't know how to approach. Alternative London have named their business based on this assumption ('the alternative'), and open their home page statement thus: 'Discover the London you won't find in the guidebooks with London's original off-the-beaten-track tour provider!' The East End is presented as synonymous to 'the real London' and words such as 'vibrant', 'authentic' and 'creative' are often used to describe the spatial experience of these tours. From 'incredibly dynamic' (SAL), to 'a vibrant and colourful culture of street art, murals, 
cafes, bars, galleries, restaurants, fashion and markets' and 'an ever-changing kaleidoscope of energy and creativity' (SSA), Shoreditch is praised as one of London's top destinations, and these tours present themselves as a perfect introduction to the scene. Although street art remains the object of the tours, the promise of immersion in the real, authentic culture of East London is a decisive hook for many of their patrons.

However, when taking a closer look at the routes of street art tours, it quickly becomes evident that the spatial knowledge they build on is not particularly distinctive, as their trajectories often overlap, intersect and coincide. Routes span the territories of Tower Hamlets, Hackney and Islington boroughs, using the City of London as a geographic and conceptual point of reference which helps define Shoreditch as edgy and the edge. As was the case with the few artists who polarized the discourses of tour guides, the geographies of their walks also concentrate around a few focal points, buildings, streets or car parks, which form the spatial nodes of London's street art walking tours.

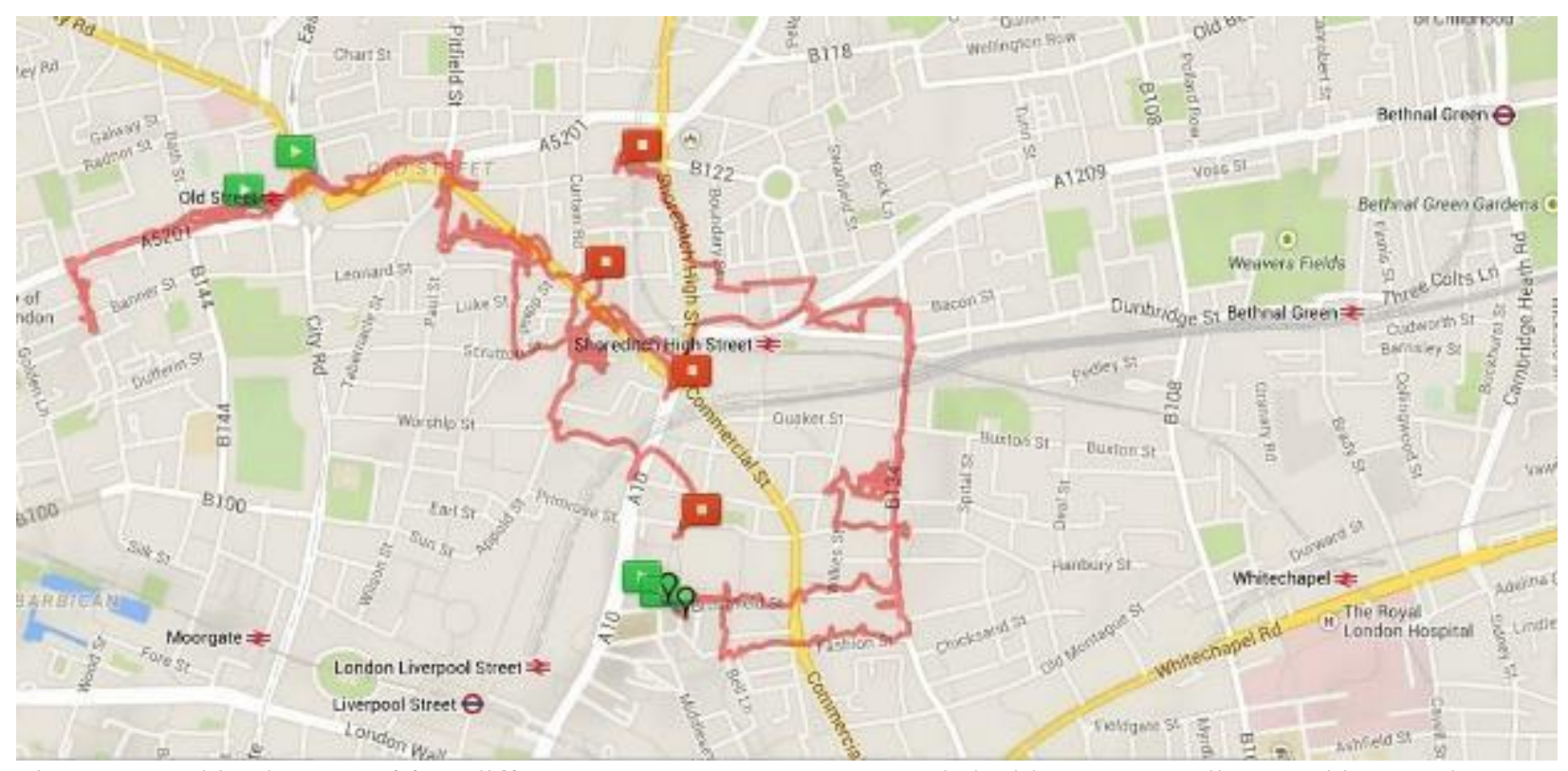

Figure7. Combined routes of four different tours, January 2015, recorded with MapMyWalk app. This map shows the limited, Shoreditch-focused territory covered by the tours, and their many overlapping routes.

The guides' discourses and their movement through the city have formative powers, not just descriptive or analytical ones. They announce a certain type of space to their participants, therefore pre-dicting their expectations and making them contribute to the fulfillment of the prediction. Participants will not only be looking to have their expectations met while taking the 
tour, but they will perpetuate the same representations of space they are being offered at the beginning of the tours. The localized design of the tours assumes that 'this is where you should see street art', which is then performed as an unquestionable fact about the geographies of London's street art. Not only are they reduced to a single limited perimeter, but they are also encouraged to perpetuate in the same place, where visibility is stronger and there is a wider guaranteed audience.

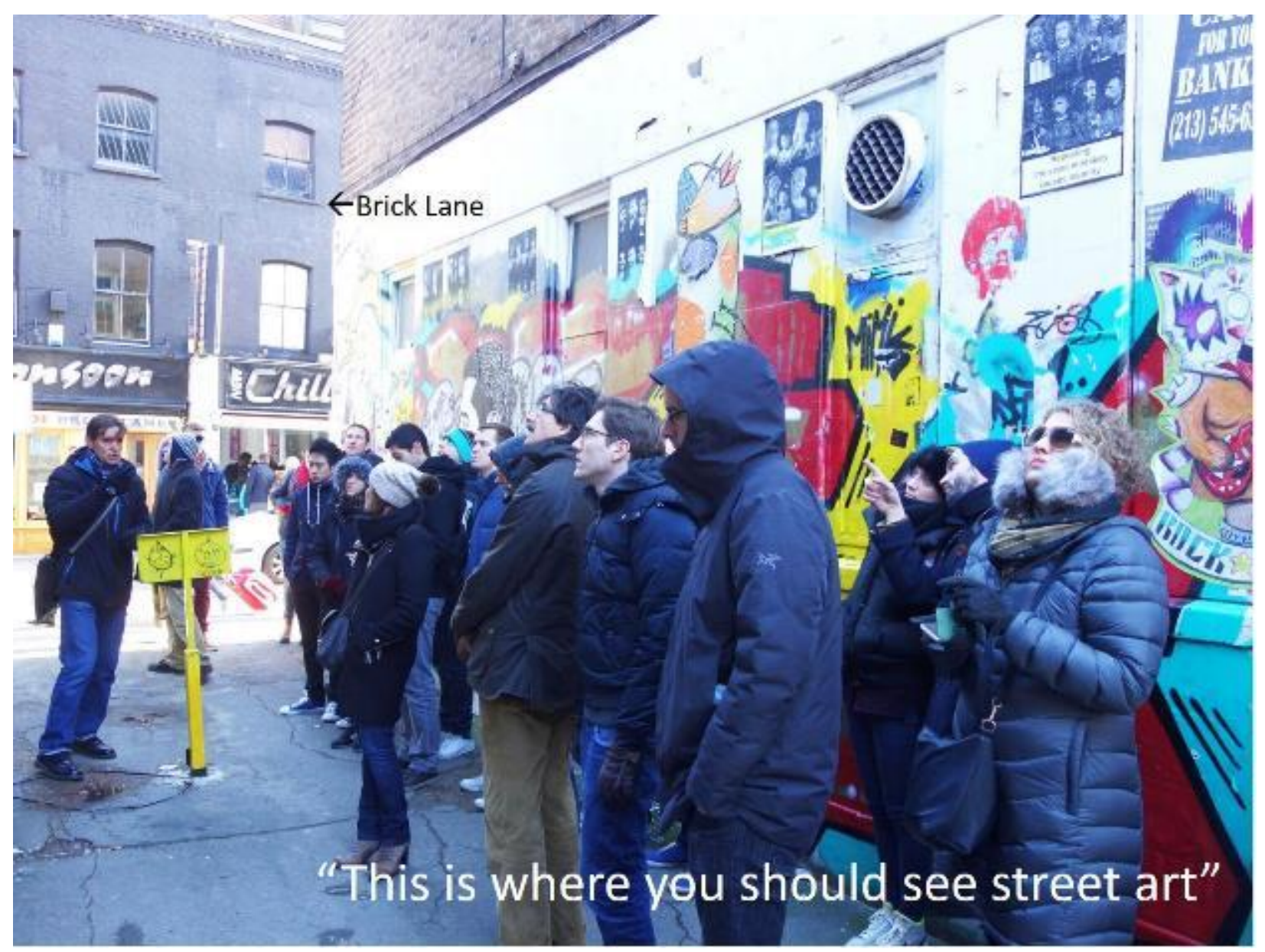

Figure8. This Brick Lane car park is a focal point for street art walking tours.

\section{Competitive cities: street art as imposed urban brand}

In his work on creativity and the Creative City (2015), geographer Oli Mould argues that Creativity (as represented by the creative city paradigm) is politically systemic, but it also appropriates and reproduces alternative, subversive creative practices. To do this, creative city economies redirect city funding away from low income housing, immigrant communities and 
social services, searching for 'quick fixes' in the form of large flagship developments such as art galleries and museums (Banet-Weiser 2012: 97). However, creative cities agendas are also supported by micro-activities associated with small scale cultural entrepreneurialism and activism, such as street art tours (O’Connor 2010: 42). In his literature review of cultural and creative industries, O'Connor identifies the urbanity of city life, or streetness, as a crucial resource for all kinds of cultural activities, among which street art tours are principal players. In fact, urbanity and creativity are fundamental to the activity of tours, and being able to identify artefacts, places and inscriptions as possessing streetness can likely make or break the business. This affords just the right balance of subcultural kudos to the legitimized practice of street art, which is branded and supported as a form of grassroots artistic movement to help implement a creative cities political agenda. As Mould argues (2015: 4),

the Creative City, despite rhetoric and 'spin' to the contrary, is ultimately reducing [subcultural] activities to economically determined instruments of urban development and politically, conceptually and linguistically whitewashing any transgressional, subversive or resistive characteristics in favour of more putative urban and economic development aims that can be homogenised and replicated. 


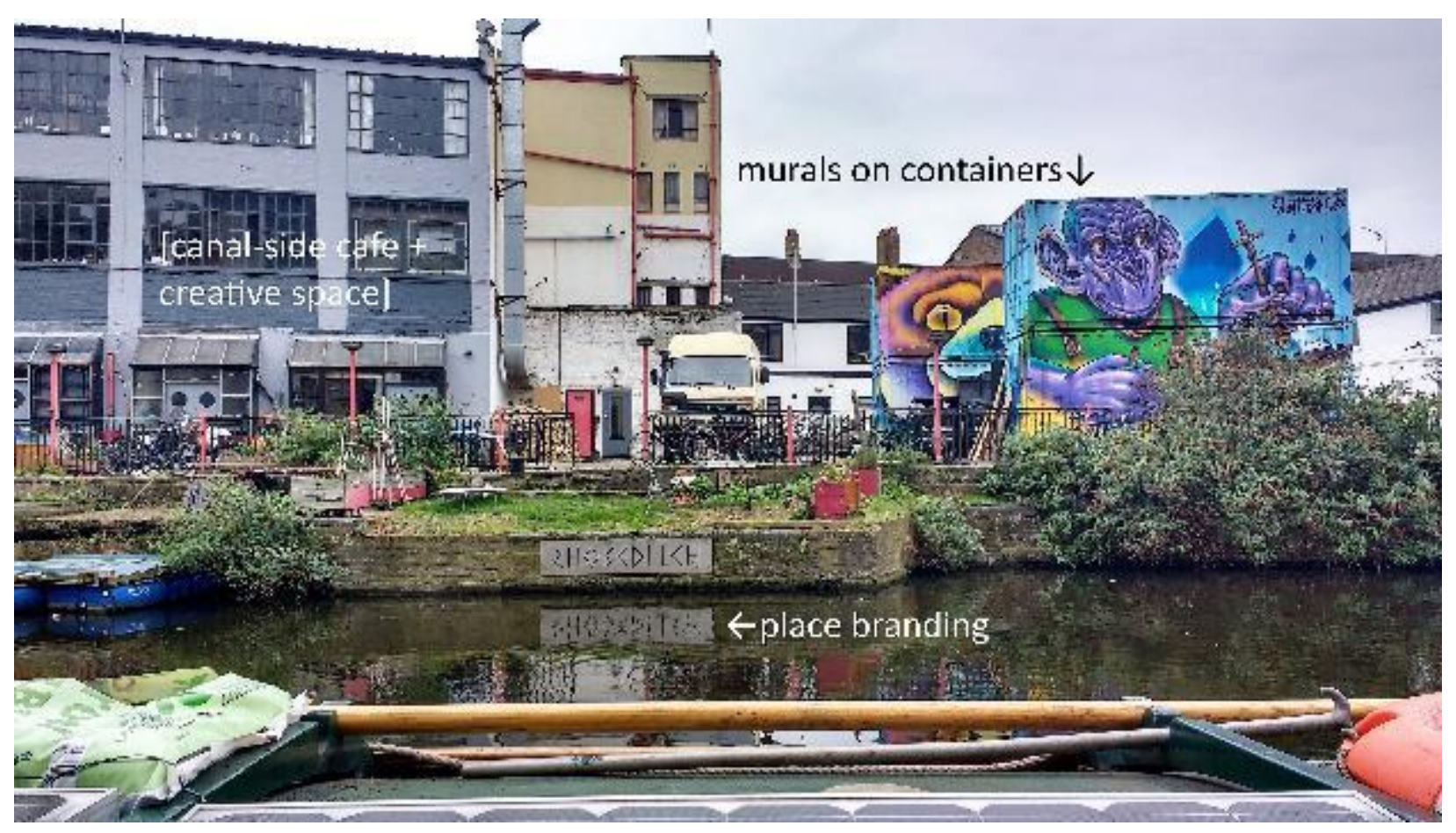

Figure 9. Producing the creative cities agenda through small-scale cultural activities. Note the reflected Shoreditch sign on the side of the canal used as an instrument of place branding.

Given the promise of the creative city, the integration of street art into its market economies is often seen as the best alternative to the criminalization of surface inscriptions (see McAuliffe 2012 and Snyder 2009). For inscriptions to be rescued from criminality status, the most obvious solution is to make them useful to local governance and its ideas about creativity and urban development; in other words, make them art. Brighenti defined this as a divergent synthesis, through which graffiti is criminalized, while street art is simultaneously eulogized, and the latter is enabled to become a creative and commercial endeavor (Brighenti 2016, see also Ferrell 2016). Street art and muralism can then be welcome in the creative city circuit, often as part of public-private partnerships to foster the production of spaces which are attractive to the creative class.

With the emergence of public-private partnerships within cities, as well as the general corporatization of cities, the 'graffiti problem' became, at least for some marketers, a way to harness 'street' creativity as part of a new way to image-market cities. (Banet-Weiser 2011: 646) 
Marketing cities efficiently becomes an imperative in a globalized culture of urban rankings and competitions. This notion of competition between cities came up during one of the tours in relation to which was the best city in the world for street art, illustrating how street art holds relevance at international level with respect to urban achievement. Performance and competition have been identified as defining functions of the creative city, alongside a neoliberal urban agenda based middle class consumption, place marketing and branding, homogeneity and replicability (Peck 2005, Valverde 2012, Pratt 2011, Hayward 2004, Mould 2015). Many of the changes in attitude towards surface inscriptions seem to be underlined by a desire to implement such agendas, and sell places - and cities - through a carefully managed support for street art.

The success of creativity-enabling policies can be measured in the fluctuation of real estate: the more property prices go up, the clearly demand for place gets reflected, fostering a marketable place identity (Peck 2005, Mathews 2010). Pratt explains that culture industries are short lived and often rapidly replaced by residential development with little space or opportunity for cultural producers (Pratt and Hutton 2009: 1043). Cultural production either ends up being pushed out of such locales, or supported in the form of endorsed, curated, programmatic activities, such as tours and festivals. One need only to look at the changing skyline of Shoreditch to recognize how former council estates are being turned into boutique hotels, car parks are becoming high rise residential blocks and warehouse spaces are transformed into pop-up cafes and fashion shops: street art enables the changes and it symbolically endorses them from the hoardings of construction sites, which it now occupies legally and with permission:

Under the hegemony of the creative city narrative, street art has been wielded into an urban development tool, targeting specific neighbourhoods and areas [...] In the public discourse, street art has thus provided something like a mirror into which the contemporary city could mirror itself, finding beauty for once - after decades of ugliness! (Brighenti 2016: 123)

By encouraging the presentation of street art and muralism as area brands, local governance not only defines the limits of acceptable creativity, but it also perpetuates a series of problems which have been signaled repeatedly by critics of creative cities. These include selling culture as product, not as production (Pratt 2009, Mathews 2010); branding culture as a normative 
imposition (Pratt 2011, Banet-Weiser 2012, Mould 2015); and overlooking the non-creatives, minor or non-competitive creatives. Thousands of non-spectacular inscriptions which partake in surface dialogues through multiplicity and presence; graphic traces of claims to the right to the city; and a whole array of non-spectacular visual displays, are left on the margins of acceptable creativity and deemed non-lucrative, and therefore non-consequential.

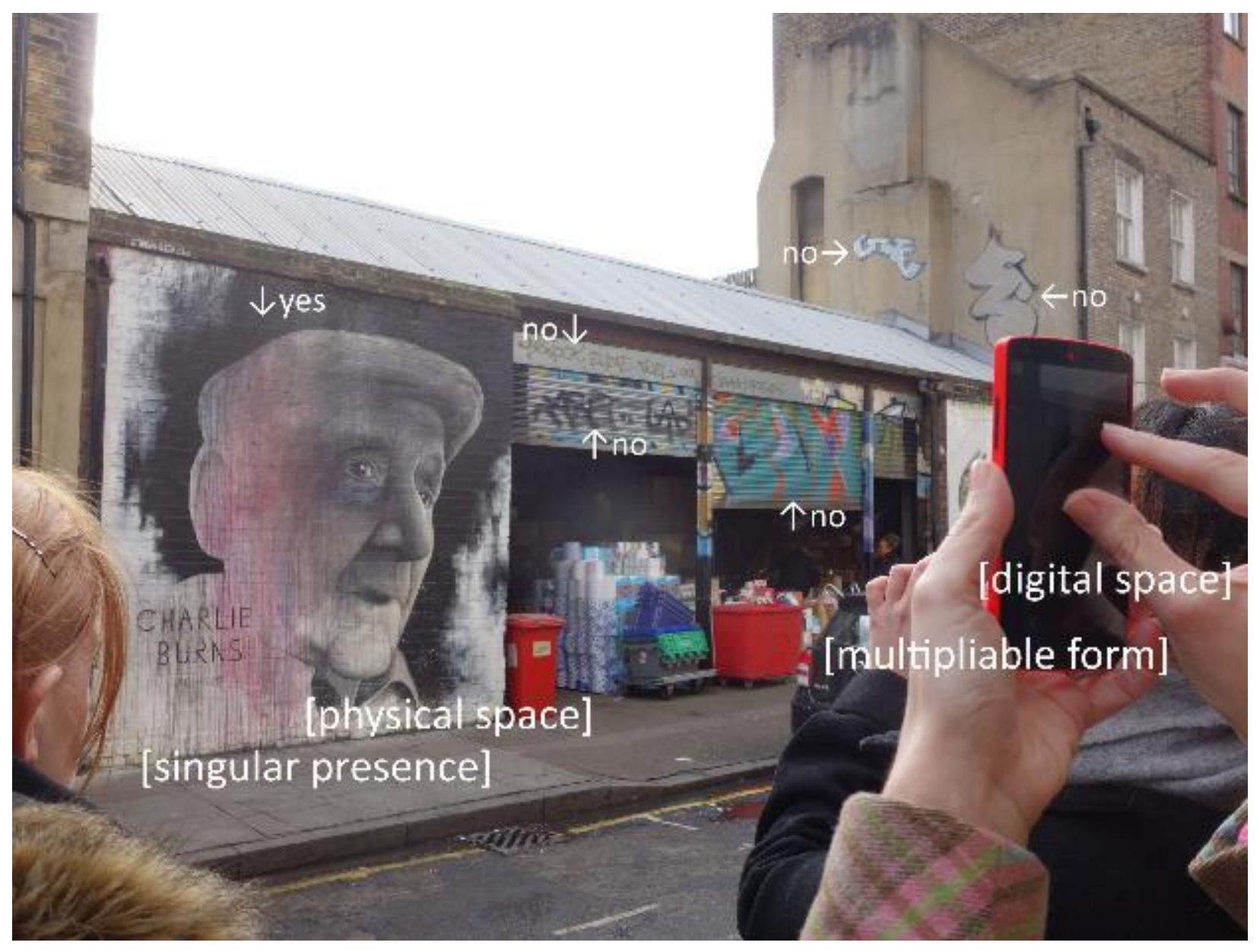

Figure 10. Very few inscriptions are selected as part of the tours discourse, and afforded a clearly identifiable status. This portrait by Ben Slow becomes the focus of participants' attention and camera phones, enabling digital versions of the image to circulate and multiply beyond its physical location.

\section{Urban change and corporate art}

Tours reflect differently on their own roles in these processes of urban change. Alternative London focus on the cultural history of Shoreditch as much as they do on the street art, presenting a history of immigration waves in the area. The entire AL tour is built around a 
rhetoric of a disappearing culture which we are witnessing but cannot do anything about: 'Community, culture, arts and history are sacrificed for economic growth but at what cost?'. Street art represents a small part of this equation and, while participants are encouraged to enjoy it, they are constantly being made aware of local histories and transformations. The role street art plays in gentrification is not however addressed, and neither is the impact of the tours. Between them, street art tours bring hundreds, if not thousands of tourists to the area on a weekly basis, who in turn contribute to the local economy and help boost the symbolic value of the area. In fact, it might be that the tours contribute to the gradual disappearance of their own material, as new financial interests start setting up camp in the area.

David Stuart of Shoreditch Street Art Tours argued that the touring industry had nothing to do with these changes, and street art was not impacting gentrification in any way:

Gentrification and redevelopment in Shoreditch has nothing to do with street art and its popularity. Buildings are not coming down because of street art. The new developments are not social developments, they are profitable, fueled by a growing population, changing lifestyles and ethnic mixes in the area. Street art lives off it, but it's not causing it. (interview January 2015)

The relationship between creative practices and real estate development is of course more complex than this (seen the discussion of Cultural Quarters and Media Cities in Mould 2015), and it is sufficient to look at the extent to which street art prefigures and then embellishes so many construction sites around Shoreditch, to understand some of the intricate connections between art and gentrification. 


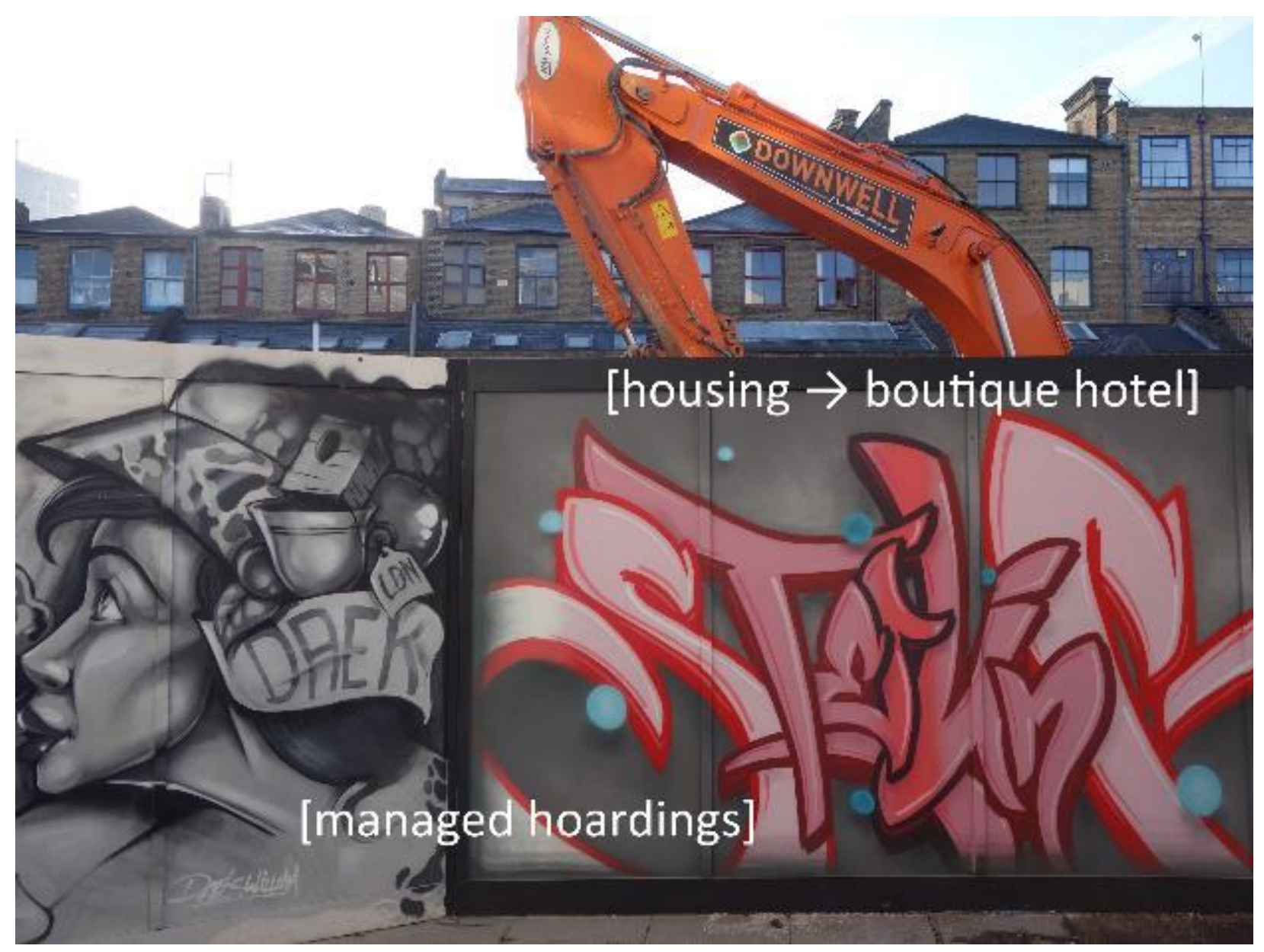

Figure 11. Street art symbolically fronting urban change: this site in Blackall Street used to be a modernist housing block, and is now being transformed into a hotel. The hoardings are managed by Global Street Art.

Corporate sponsorship is sometimes directly responsible for the production of wall content, through organisations that facilitate artists' access to sponsored walls, and then curate the works displayed on these walls. For example, art and advertising agency Global Street Art currently manage hoardings around several construction sites in London, as a result of partnerships with developers who seek an integration of street art into corporate branding agendas of approachability and social responsibility. For the duration of these neighbourhood-altering constructions, street art symbolically facilitates property-led redevelopment, becoming the neatly curated face of corporate appropriation, permissioned opportunity and gentrification. 
Despite all this, the critical undercurrent towards permissioned work seems to have loosened among tour guides, who tend to focus on the positive aspects of the consolidated legal mural scene in London: 'Street art went from underground to mainstream. It is now controlled and curated, but the positive side of this is that we get world class high calibre art in London'; 'Street painting is now a privileged platform because of immediate global visibility' (AL, January 2015); 'Street art went from zero tolerance to state sponsored art in five years' (SSA, January 2015); 'Perhaps street art will grow to be accepted much like photography and cinema were in the history of art, after a period of rejection' (SAL, January 2015).

Resignation aside, I would argue that this type of muralised, corporatized street art constitutes an imposition of an urban visual regime as authoritative as censorship or whitewashing. The main difference is that it is supported by a number of institutions of the creative city, it gets deployed in the name of creativity, and it puts colours and faces on walls, instead of blocks of whites and grays. Young speaks of 'artwashing' to describe how creativity is being strategically coopted into a process of urban branding, and armed with all the weapons necessary to carry out its mission (Young 2016: 98). Walking tours play their own part in the urban artwashing process, as they enable it through repeated endorsement and through a production of its audiences. 


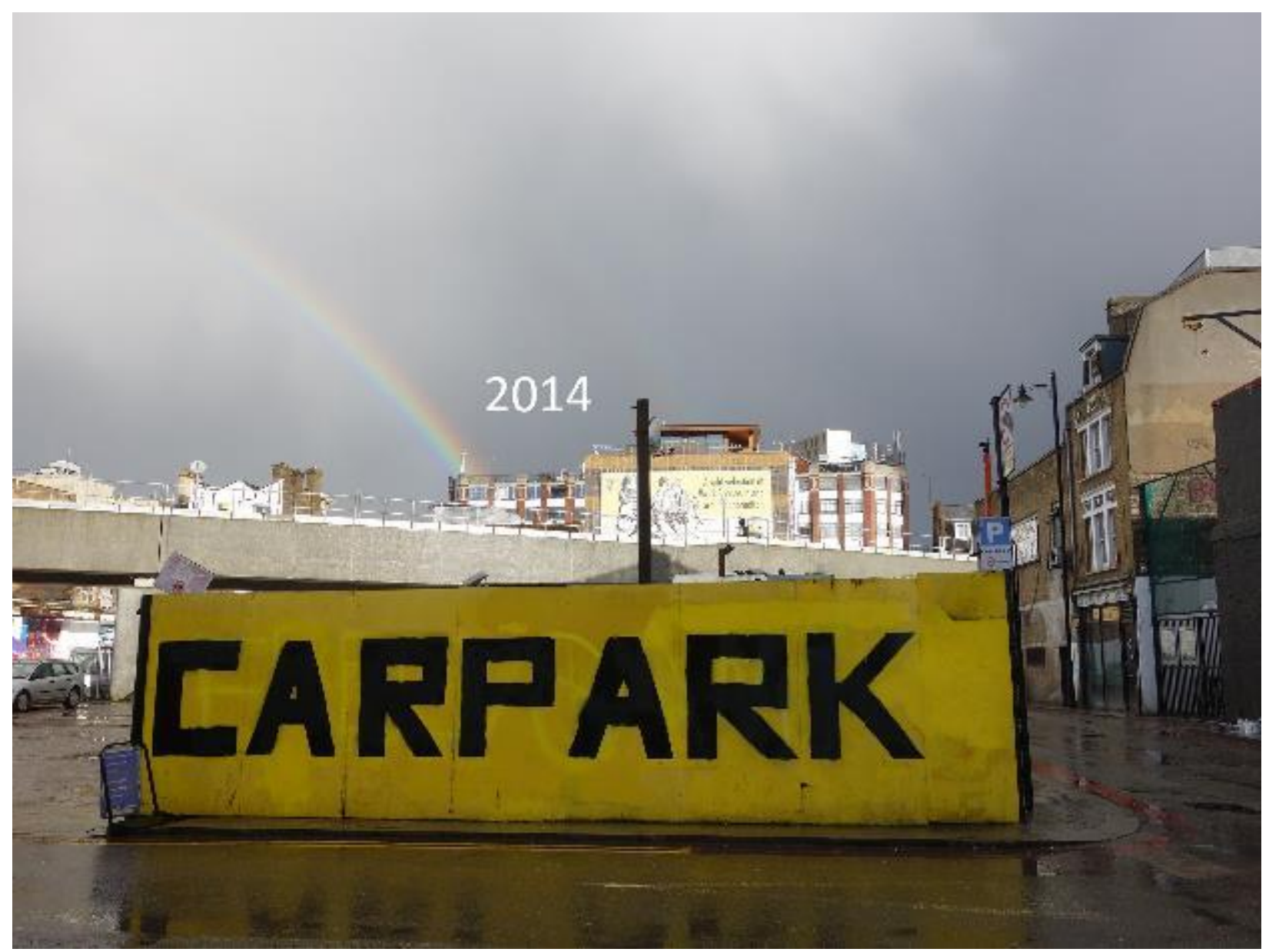

Figure 12. Facing East on King John Ct in 2014, toward a car park in the heart of Shoreditch. The car park and railway overpass used to be available surfaces for a variety of inscriptions. 


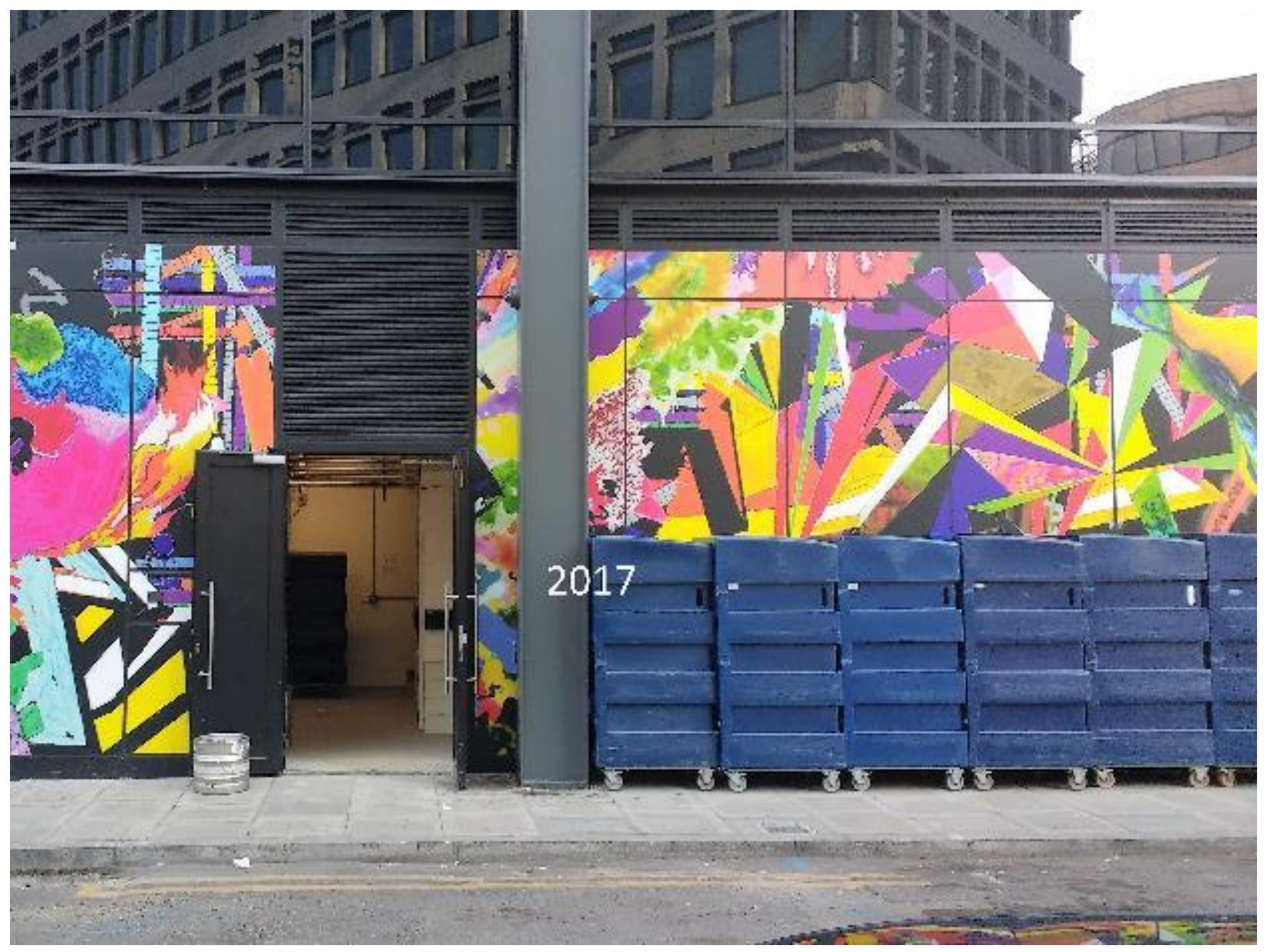

Figure 13. Facing East on King John Ct in 2017, in the same place, toward a newly opened luxury hotel. The ground level side elevations of this glass and steel high rise are covered in street-style prints, using streetness to create the appearance of an edgy, locally responsive brand.

\section{Conclusion: curating the streets}

This research was conducted in 2013-15, which means that some of the tour guides will have come and gone, and several of their referenced works will no longer be there. Some will have fallen into oblivion, while others continue to dominate the content of these walks, and implicitly the London street art world. As a few tours grew in popularity and maintained their success, others disappeared from the market, much like some of their locations got lost to a gentrification they also enabled. 
Tours exist at the very centre of the London street art world, where many street art-related activities have become the subject of place branding for the creative city. London showcases work by international artists, and is known for its generous offer of online symbolic capital, which artists gain just by visiting the city. Areas such as Shoreditch carry curated visual displays on the sides of their hoardings, using neatly painted murals to mask the displacement which street art had symbolically supported. Spaces become saturated with the discourses of endorsement that street art tours help perpetuate, leaving little room for marks which fall outside clearly defined creative agendas. This is the street art world of the capital: it is not its representation, interpretation or collateral effect: the murals, the curation and the tours are all agents of this world, building upon each other's actions to create an art world of high prestige and global relevance, often to the detriment of local independent wall writing cultures.

When street art is declared acceptable, it is because it is aimed to become part of the identity of a place, and Shoreditch is a good example of how street art went from independent production to urban brand in the space of 10-15 years. The next phase is for the brand to become completely devoid of content, and left only with a highly-regulated version of corporate hoarding art, until all surfaces that could have supported autonomous voices are gone, and replaced by the carefully coated shine of high-end developments.

When the tours of the future come to Shoreditch, they might be tours of urban memory, where guides invoke past works from the glass elevations of the most recent high rises, and participants use augmented reality apps to 'see' into the pluri-vocal past through the screens of their devices. Surfaces which are still there will bear symbolic traces of works that were painted over, or weathered away, and places will become iconic because of these desirable absences. However, when even the surfaces are gone, there will be little left to show or tell, except how the showing and telling itself played a part in the gradual disappearance of its object. Where will all the inscriptions be, and where will the preferential art and its supportive surfaces go? Art-washed, financially-fueled, tours-enabled condos will have gone up instead, the dystopic result of removing the very thing they had banked on. In fact, they were not banking on independent surface scribblers and the buzz of multiple surface occupations at all, but on their branded, regulated versions, which will contain nothing but the aura of a city that is long gone. 
References:

Alternative London Tours (2015), http://www.alternativeldn.co.uk/, accessed 28 January 2017.

Andron, S. (2017), 'Interviewing Walls: Towards a Method of Reading Hybrid Surface Inscriptions' in Avramidis, K. and Tsilimpounidi, M. (eds), Graffiti and Street Art: Reading, Writing and Representing the City, London: Routledge.

Banet-Weiser, S. (2012), Authentic TM: Politics and Ambivalence in a Brand Culture, New York: New York University Press.

Banet-Weiser, S. (2011), 'Convergence on the Street' in Cultural Studies 25, no. 4-5: 641-58.

Becker, H., (2008), Art Worlds, Berkeley, Calif; London, University of California Press.

Bengtsen, P., (2014), The Street Art World, Lund, Almendros de Granada Press.

Bourdieu, P., (1991), Language and Symbolic Power, Cambridge, Polity.

Bourdieu, P., (1992), The Field of Cultural Production: Essays on Art and Literature, Cambridge, Polity Press.

Brighenti, A. M. (2017), 'Expressive Measures. An Ecology of the Public Domain' in Avramidis, K. and Tsilimpounidi, M. (eds), Graffiti and Street Art: Reading, Writing and Representing the City, London: Routledge.

Brighenti, A. M. (2016), 'Graffiti, street art and the divergent synthesis of place valorisation in contemporary urbanism' in Ross, J. I. (ed.), Routledge Handbook of Graffiti and Street Art, London: Routledge.

Cresswell, T. (1996), In Place/Out of Place: Geography, Ideology, and Transgression. Minneapolis; London: University of Minnesota Press, 1996.

Dickens, L. (2010), 'Pictures on Walls? Producing, Pricing and Collecting the Street Art Screen Print' in City: Analysis of Urban Trends, Culture, Theory, Policy, Action. 14, no. 1-2: 63-81.

Evans, G. (2016), 'Graffiti Art and the City' in Ross, J. I. (ed.), Routledge Handbook of Graffiti and Street Art, London: Routledge.

Ferrell, J. (2016), 'Graffiti, Street Art and the Dialectics of the City' in Ross, J. I. (ed.), Routledge Handbook of Graffiti and Street Art, London: Routledge. 
Hallin, A. and Dobers, P., (2012), 'Representation of Space. Uncovering the Political Dimension of Guided Tours in Stockholm', Scandinavian Journal of Hospitality and Tourism 12, no. 1: 826.

Hayward, K. (2004), City Limits: Crime, Consumer Culture and the Urban Experience, London: GlassHouse.

Keenan, S. (2015), Subversive Property: Law and the Production of Spaces of Belonging, Milton Park, Abingdon, Oxon; New York, NY: Routledge.

Mathews, V. (2010), 'Aestheticizing Space: Art, Gentrification and the City' in Geography Compass 4, no. 6: 660-75.

Mcauliffe, C. (2012), 'Graffiti or Street Art? Negotiating the Moral Geographies of the Creative City', in Journal of Urban Affairs 34, no. 2: 189-206.

McAuliffe, C. (2013), 'Legal Walls and Professional Paths: The Mobilities of Graffiti Writers in Sydney' in Urban Studies 50, no. 3: 518-37.

Mould, O. (2015), Urban Subversion and the Creative City, London: Routledge, 2015.

Mykletun, R., (2013), 'IRFGT 2013: Third International Research Forum on Guided Tours', Scandinavian Journal of Hospitality and Tourism 13, no. 3: 269-71.

O'Connor, J. (2010), The Cultural and Creative Industries: A Literature Review, 2nd ed., Newcastle upon Tyne: Creativity, Culture and Education.

Peck, J. (2005), 'Struggling with the Creative Class' in International Journal of Urban and Regional Research 29, no. 4: 740-70.

Pratt, A. (2011), 'The Cultural Contradictions of the Creative City' in City, Culture and Society 2, no. 3: $123-30$.

Pratt, A. and Hutton, T. (2009), 'Urban Regeneration: From the Arts 'Feel Good' Factor to the Cultural Economy: A Case Study of Hoxton, London' in Urban Studies 46, no. 5-6: 1041-61.

Proud, A., 'Why This "Shoreditchification" of London Must Stop', in The Telegraph, 12 January 2014: http://www.telegraph.co.uk/men/thinking-man/why-this-shoreditchification-of-londonmust-stop/, accessed 30.03.2017.

Schacter, R. (2014), Ornament and Order: Graffiti, Street Art and the Parergon, Farnham: Ashgate. 
Schacter, R. (2015), 'From Dissident to Decorative: Why Street Art Sold Out and Gentrified our Cities', in The Conversation, 9 November 2015.

Shoreditch Street Art Tours (2015), http://www.shoreditchstreetarttours.co.uk/, accessed 28 January 2017.

Snyder, G. (2009), Graffiti Lives: Beyond the Tag in New York's Urban Underground, New York; London: New York University Press.

Street Art London Tours (2015), http://streetartlondon.co.uk/tours/, accessed 28 January 2017.

Valverde, M. (2012), Everyday Law on the Street: City Governance in an Age of Diversity, Chicago Series in Law and Society.

Young, A., (2016), Street Art World, London, Reaktion Books.

Zillinger, M., Jonasson, M., and Adolfsson, P., (2012), 'Guided Tours and Tourism', Scandinavian Journal of Hospitality and Tourism 12, no. 1: 1-7. 